\title{
Effect of Artemisia annua L. as Substitute to Sulfonamides (Sodium Sulfadimerzine) on Coccidiosis and Growth Performance in Rabbits
}

\author{
Hippolyte Mekuiko Watsop ${ }^{\text {* }}$, Djibrilla Nabilatou ${ }^{2}$, Jules Lemoufouet ${ }^{3}$, Ronald Vougat Ngom¹, \\ Emile Miegoue $^{3}$, Mouchili Mama ${ }^{3}$, Mamoudou Abdoulmoumini², Tendonkeng Fernand ${ }^{3}$
}

\author{
${ }^{1}$ Department of Animal Productions, School of Veterinary Medicine and Sciences, University of Ngaoundere, Ngaoundere, \\ Cameroon \\ ${ }^{2}$ Department of Parasitology and Parasitological Diseases, School of Veterinary Medicine and Sciences, University of Ngaoundere, \\ Ngaoundere, Cameroon \\ ${ }^{3}$ Department of Animal Productions, Faculty of Agronomy and Agricultural Sciences, University of Dschang, Dschang, Cameroon \\ Email: *hippolytewatsop87@gmail.com
}

How to cite this paper: Watsop, H.M., Nabilatou, D., Lemoufouet, J., Ngom, R.V., Miegoue, E., Mama, M., Abdoulmoumini, M. and Fernand, T. (2022) Effect of Artemisia annua L. as Substitute to Sulfonamides (Sodium Sulfadimerzine) on Coccidiosis and Growth Performance in Rabbits. Open Journal of Animal Sciences, 12, 159-170. https://doi.org/10.4236/ojas.2022.122012

Received: February 1, 2022

Accepted: February 25, 2022

Published: February 28, 2022

Copyright $\odot 2022$ by author(s) and Scientific Research Publishing Inc. This work is licensed under the Creative Commons Attribution International License (CC BY 4.0).

http://creativecommons.org/licenses/by/4.0/

\begin{abstract}
Coccidiosis is a disease caused by protozoa of the genus Eimeria which seriously affects young rabbits. Treatment based on the use of anticoccidial drugs is increasingly ineffective due to the rapid emergence of resistant strains of coccidia and the high cost of drugs. Consumer demand for rabbit products without chemical residues led to a growing interest in the use of medicinal plants as an alternative treatment for coccidiosis. The present study was carried out during the period of August to December 2020 to assess the anticoccidial effect of hydro-ethanolic extract of leaves of Artemisia annua L., in young rabbits. The antiparasitic efficacy of Artemisia extract was tested on 15 young rabbits (whose age varied between 7 and 9 weeks) divided into 5 lots of 3 animals. The average weight of these animals was $790 \mathrm{~g}$. The results of this study show that the feces samples and the weight of young rabbits before administration of the treatment and the coprological examination (every 7 days for 4 weeks) show a fecal excretion reduction rate (FECRT) of $55.13 \%$ in the lot treated by sulfonamide. On the other hand, in animals received treatments extract of the leaves of Artemisia annua L., the average FECRT is evaluated at $69.64 \%, 79.22 \%$, and $96.36 \%$ for respective doses of 400,800 and $1200 \mathrm{mg} / \mathrm{kg}$ bodyweight and proves their anticoccidial effect. Furthermore, the variation in mean Eggs Per Gram (EPG) of coccidia and the average weekly weight gain (AWWG) of each lot were significant in the lots treated with hydro-ethanolic extract $(\mathrm{P}<0.05)$. The greatest reductions in oocystal excretion and weight gain obtained were those of lot 5 , treated at $1200 \mathrm{mg} / \mathrm{kg}$ of hydro-ethanolic leaves extract of Artemisia annua L.
\end{abstract}




\section{Keywords}

Coccidiosis, Rabbit, Artemisia annua L., Sulfonamide, Hydroethanolic Extract, Anticoccidial Activity

\section{Introduction}

Livestock farming is increasingly directed towards an intensification of production systems in order to meet the socio-economic requirements linked to the population explosion and a food deficit. This intensive production has comparative advantages in terms of animal productivity [1]. To face this problem, the promotion of livestock farming, especially short-cycle species, remains a necessity to produce meat [2]. Rabbit (Oryctolagus cuniculus), due to its ease of rearing combined with high productivity, is a species that can effectively contribute to the increase in animal protein needed by African populations [3] [4]. According to Lebas and Colin [5], rabbit meat production in Cameroon is 0.6 tons/year for an average consumption of $0.41 \mathrm{~g} /$ inhabitant/year for an estimated population of 25 million inhabitants. It remains insufficient, hence the need to move towards a large-scale production. However, it intensifies zoohygiene problems [6]. According to many studies [2] [7] [8] coccidiosis is one of the main constraints that damage the development of livestock and causes enormous economic losses. In rabbit breeding, it remains one of the major health problems [9]. In addition, it causes important economic losses worldwide [10] [11].

Coccidiosis (infection with coccidia) is a disease of rabbits caused by a class of single-celled organism known as protozoa which is developed in the digestive tract [12]. This disease can be contracted from the environment and usually is present in multi rabbit situation as well as in shelters/breeding establishments where stocking rate are high and rabbits are kept in communal runs. Generally, the infections remain subclinical with consequences such as reduced growth or weight loss. But eimeriosis can also be deadly, especially in young rabbits [12]. Furthermore, by reducing the immunity of the host, infections by Eimeria species could favour other diseases [13]. The control of this infection in livestock farms is essential for the improvement of productivity, especially in cuniculture. This is why molecules with anticoccidial activity were developed. However, a lot of anti-coccidial medications to prevent Eimeria infection have revealed the decreased efficacy because some Eimeria species have developed resistance activity to anti-coccidials [14]. Recently, phytochemicals from different types of botanical elements have been explored as sustainable alternatives to combat coccidiosis and much more, influence zootechnical performance [15]. Due to the growing demand of "organic meat" and the development of antimicrobial resistance on the other hand, current research efforts are moving towards the use of plant extracts. Due to their therapeutic properties, several species belonging to the genus Artemisia, have attracted more attention from researchers in recent years. Many 
of them have antiparasitarian properties [16]. The anticoccidial effects of certain species as well as their effects on the parameters of growth have also been showed with the active ingredient lactone sesquiterpenes, of which artemisinin is the most important [17] [18] [19]. This study aimed in evaluating the anticoccidial activity of the hydro-ethanolic extract of the leaves of Artemisia annua L. and the weight gain of animals treated with both phytotherapy and conventional therapy.

\section{Material and Methods}

\subsection{Description of the Study Area}

This study was conducted within the National Veterinary Laboratory (LANAVET) of Bockle located in the North region of Cameroon in the Benoué department and Garoua 3 sub-division ( $9^{\circ} 15^{\prime} 35.19618^{\prime \prime}$ North latitude; $13^{\circ} 27^{\prime} 18.20196^{\prime \prime}$ East longitude). The study was conducted from August to December 2020. The climate in this area is tropical type characterized by a long dry season from October to April and a short rainy season from May to September. The average annual rainfall is $1000 \mathrm{~mm}$. Temperatures remain high with an average of $28^{\circ} \mathrm{C}$ with maxima reaching $40^{\circ} \mathrm{C}-45^{\circ} \mathrm{C}$ in March and April.

\subsection{Plant Material Collection}

A. annua L. was collected in August 2020, in the Adamawa region of Cameroon, whose altitude is about $1200 \mathrm{~m}$ and identified at the National Herbarium of Cameroon in comparison with the material of Ngansop 682 of the specimen of the herbarium collection $\mathrm{N}^{\circ} 67448 / \mathrm{HNC}$. An herbarium was made for this purpose. The harvest of the leaves of $A$. annua $\mathrm{L}$. consisted of pinching one end of the twigs between thumb and forefinger to tear leaves along the stem. This method has the advantage of giving very clean material and solving the problem of subsequent separation of leaves and stems [20]. The leaves were dried in the oven at $30^{\circ} \mathrm{C}$ for constant drying without temperature variation for 5 days. After drying, they were crushed with an electric grinder (KENWOOD brand) to obtain a powder which was sieved ( $1 \mathrm{~mm}$ of mesh) and then kept in a hermetically closed box and placed in a place away from light and heat.

\subsection{Animal Material}

Fifteen (15) post-weaned young rabbits of common breed whose age varied between 7 and 9 weeks were the subject of the experiments. The average weight of these animals was $790 \mathrm{~g}$. Water and feed were distributed ad libitum to the animals. The feed (Table 1) was formulated within the LANAVET, without anticoccidials and distributed till the end of the experiment, as well as banana leaf tops which serve as fiber source.

\subsection{Preparation of the Hydroethanolic Extract}

The dried leaves of Artemisia annua L. were ground as describe above for $A$. 
Table 1. Nutritive value of the diet.

\begin{tabular}{cc}
\hline Components & Quantity (\%) \\
\hline Maize & 32 \\
Cotton cake & 13 \\
Corn bran & 53 \\
Salt & 0.97 \\
Bone powder & 0.7 \\
Olivitasol & 0.06 \\
\hline
\end{tabular}

annua L. The powder (128.5 g) was macerated with a hydroalcoholic mixture $(1285 \mathrm{ml})$ in the proportions 70 volumes of ethanol/30 volume of distilled water at room temperature and away from light for 24 hours. Subsequently, the mixture obtained was first filtered on gauze and a second time on filter paper (Figure 2). This operation was repeated a 2nd and a 3rd time with renewal of the solvent. The three hydro-ethanolic extracts have been brought together [21] [22] and put in the oven for drying at $40^{\circ} \mathrm{C}$. The dry extract was stored in the refrigerator at $4^{\circ} \mathrm{C}$ till use.

\subsection{Plant Yield}

After drying operation of the leaves of the annual mugwort we obtain $300 \mathrm{~g}$ of powder from $1200 \mathrm{~g}$ fresh leaves, for a yield of $25 \%$. The extraction by maceration of this powder in ethanol/distilled water in the proportions 70/30 allow us to obtain $31.25 \mathrm{~g}$ of dry crude extract of dark green color with a yield of $24.3 \%$ relative to the total weight of the leaves powder. Hydroethanolic solution was used for extraction because many studies have already showed the anti-coccidial activity of ethanol extract of plants [23] [24]. In addition, ethanol has the capacity to extract many actives compounds like tannins [25] which showed their efficiency against Eimeria species [26].

\subsection{Animal Care}

The young rabbits were placed in individual iron cages. Each was $70 \mathrm{~cm}$ long, 50 $\mathrm{cm}$ wide and $50 \mathrm{~cm}$ high. These cages were individually isolated to facilitate the collection of fecal matter. Each cage was equipped with a feeder and a drinker.

\subsection{Sampling}

The rabbits were divided into 5 lots of 3 animals according to the treatments to be administered.

Lot 1: Infected, Not treated;

Lot 2: Infected, Treated with sodium sulfadimerzine $50 \mathrm{mg} / \mathrm{kg}$ live weight for 10 days;

Lot 3: Infected, treated with hydro-ethanolic extract of leaves of $A$. annua L. at $400 \mathrm{mg} / \mathrm{kg}$ live weight, single dose; 
Lot 4: Infected, treated with hydro-ethanolic extract of $A$. annua L. leaves at $800 \mathrm{mg} / \mathrm{kg}$ live weight, single dose;

Lot 5: Infected, treated with hydro-ethanolic extract of $A$. annua L. leaves at $1200 \mathrm{mg} / \mathrm{kg}$ live weight, single dose.

The reference drug used in this study was an anticoccidial named Antiococsuper (active ingredients: sodium sulfaimerzine, lot number: PBO-002361, laboratory: QALIAN)

The anticoccidial was administered to the animals in drinking water as indicated by the manufacturer and administered by gavage using an electronic pipette to ensure that the extract was actually taken by the young rabbits.

\subsection{Parasitological Data}

Individual fecal samples were taken and analyzed on days $7 ; 14 ; 21 ; 28$. Fresh droppings were collected using gloves in plastic jars early in the morning. Each jar was labelled with the information of the animal and the lot.

\subsubsection{Coprologic Analysis}

The flotation method for a qualitative approach and that of Mc Master for egg research and enumeration were used for coproscopic analyses [27].

The flotation method consisted of mixing $3 \mathrm{~g}$ of feces in $45 \mathrm{ml}$ of $\mathrm{NaCl}$ solution and then sieving with, forming a meniscus on the surface of the tube and finally affixing a lamella on said meniscus. After about ten minutes, the lamella was deposited on the slide so as to adhere to it for observation under a microscope [28].

For the Mc Master method, four grams (4 g) of feces were taken from each sample and crushed in a porcelain mortar by adding gradually $60 \mathrm{ml}$ of the saturated solution of $\mathrm{NaCl}$ (Willis solution). Subsequently, the mixture was filtered through a tea strainer, lined with a gauze previously placed in the tea strainer. The filtrate was homogenized 20 minutes later using a spatula. During stirring, a sample of the suspension was taken using a pipette for filling the Mc Master blade chambers, with preventing the formation of air bubbles. The filled slide was placed on the microscope and left five minutes before observation [29]. Egg counting was done by chambers or cells. Thus, the number of parasite eggs per gram of feces (EPG) was obtained by multiplying the total number of eggs observed in a cell by 50 .

\subsubsection{Evaluation of the Efficacy of Medicinal Products Administered by the Fecal Egg Excretion Reduction Test}

The efficacy of the drugs was determined by calculating the fecal excretion reduction rate (FECRT) of coccidia eggs in each lot after treatment according to the [30] formula following:

$$
\text { FECRT }=\frac{\left(T_{1}-T_{2}\right)}{T_{1}} \times 100
$$

with: 
$T_{1}$ : EPG before treatment in the treated lot (at $\left.\mathrm{D}_{0}\right)$.

$T_{2}$ : EPG after treatment in the treated lot (at $\left.\mathrm{D}_{7}, \mathrm{D}_{14}, \mathrm{D}_{21}, \mathrm{D}_{28}\right)$.

\subsection{Determination of Weight Gain}

The weight of the animals was recorded during the administration of treatment and every week during the experiments. This allowed us to calculate the average weekly weight gain (AWWG) of each lot.

\subsection{Data Analysis}

Data from in vivo excretion of coccidia oocysts in rabbits, as well as weight gain were subjected to one-factor analysis of variance (ANOVA) using the general linear model.

The statistical model used was:

$$
X_{i j}=\mu+\alpha_{i}+e_{i j}
$$

$X_{i j}=$ Observation on the animal $j$ that received the treatment $i$

$\mu=$ Overall average

$\alpha_{i}=$ Effect of the dose of anticoccidial in treatment $i$

$e_{i j}=$ Residual error observed in the animal $j$ that received the treatment $i$.

When differences existed between treatments, the means were separated by the Duncan test at the $5 \%$ threshold.

Data on excretion in vivo of coccidia oocysts were compared between lots by Student's t test $(\mathrm{p}<5 \%)$.

\section{Results}

\subsection{Anticoccidial Effect of Artemisia annua L.}

\subsubsection{Fecal Egg Excretion Reduction Test}

Rates of reduction of fecal excretion of coccidia eggs per treatment lot (Table 2) shows that the rabbits of the various lots formed excreted eggs throughout the test in a variable way. Differences in the degree of animal infestation (expressed as EPG) and the rates of reduction in egg excretion levels were observed between the control lot and the different lots treated with sulphamide and plant extract at different doses. Treatment with $1200 \mathrm{mg}$ of plant extract induced a decrease of $98.54 \%$ in average EPG on day 14 and $100 \%$ on day 28 . The same observation was made for Lot 3 and Lot 4 which recorded respectively 94.14 and $97.58 \%$ of reduction in egg excretion on day 28 . In the lot treated with sodium sulfadimerzine, there was also a maximum reduction at the rate of $80.20 \%$ on the $28^{\text {th }}$ day.

\subsubsection{Average Evolution of Numbers of Oocysts per Lot}

The evolution of the number of oocysts per gram of feces (EPG) in the different groups (Figure 1) shows that the rabbits being naturally infested, the enumeration of eggs per gram of feces (parasitic load on day 0) was done before administration of any treatment, then every week after treatment within seven days. A decrease in oocystal load per gram of feces was observed from $D_{0}$ to $D_{7}$ in lots 2, 
Table 2. Reduction rate of coccidia egg excretion for different treatments.

\begin{tabular}{cccccc}
\hline \multirow{2}{*}{$\begin{array}{c}\text { Post-processing } \\
\text { period }\end{array}$} & Lot 1 & Lot 2 & Lot 3 & Lot 4 & Lot 5 \\
\cline { 2 - 6 } & -850.88 & 17.18 & 31.18 & 52.63 & 88.35 \\
Day7 & -547.37 & 52.98 & 64.52 & 76.31 & $98.54^{\star}$ \\
Day $_{14}$ & -314.03 & 70.17 & 88.71 & 90.35 & $98.54^{\star}$ \\
Day 21 & 76.84 & 80.20 & 94.14 & $97.58^{*}$ & $100^{\star}$ \\
Day28 & -408.86 & 55.13 & 69.64 & 79.22 & $96.36^{\star}$ \\
\hline
\end{tabular}

FECRT: "Fecal Eggs Reduction Count"; *: A reduction > 95\% indicates the absence of resistance to the product used for treatment.

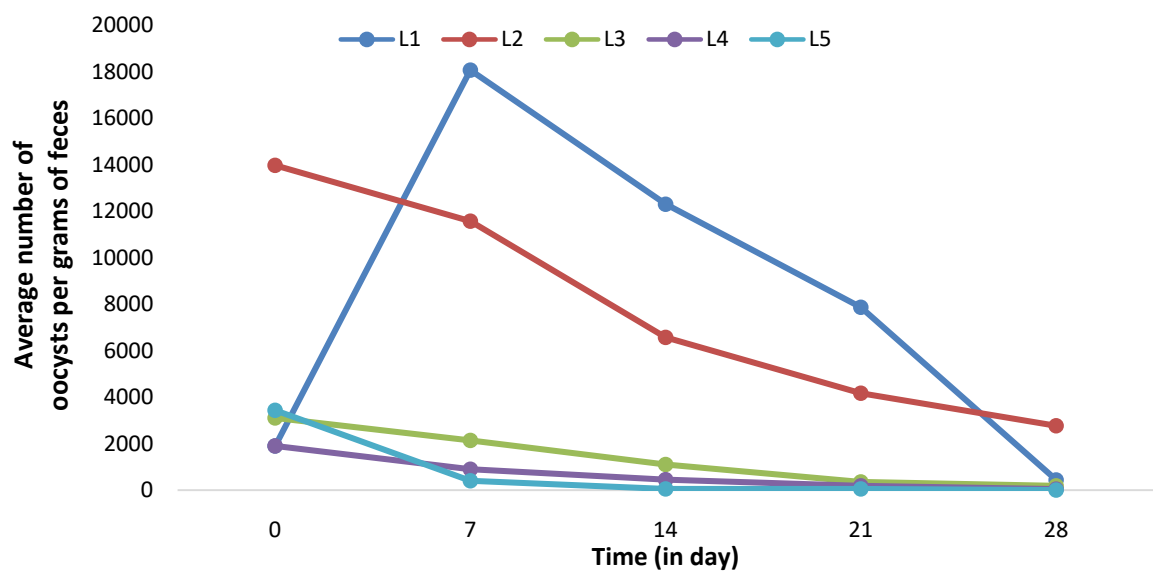

Figure 1. Evolution of number of oocysts per gram (EPG) of feces.

3,4 and 5 respectively treated with sodium sulfadimerzine at $50 \mathrm{mg} / \mathrm{kg}$ live weight, and 400, 800 and $1200 \mathrm{mg} / \mathrm{kg}$ live weight of the hydroethanolic extract of leaves of Artemisia annua L. However, there is an increase in excretion for the same period in lot 1 that received no treatment. This average load per lot has decreased considerably for all lots from the $7^{\text {th }}$ day, to tend towards zero for lots 3, 4 and 5. It was 440 EPG on day 28 for lot 1, 2766 EPG on the same day for lot 2 and 0 EPG for lot 5.

\subsubsection{Average Parasitic Load per Lot of Treatment}

The average parasitic loads obtained during the 28 days of follow-up (Figure 2) were significantly higher for lot 2 (sulfonamide-treated) and 1 (untreated) and low for lots 3, 4 and 5, all treated with a hydro-ethanolic extract of leaves of $A$. annual $\mathrm{L}$. Thus, the parasitic loads of lots 1 and 2 were significantly higher $(\mathrm{P}<$ 0.05 with $\mathrm{F}=65.69$ and $\mathrm{N}=3$ ) than those of lots $3 ; 4$ and 5 .

\subsubsection{Mean Parasite Load Compared to Sodium Sulfadimerzine}

The average parasitic load of the batch treated with sodium sulfadimerzine (L2) and of the untreated lot and those treated with the hydroethanolic extract of leaves of Artemisia annua L. at doses of 400, 800 and $1200 \mathrm{mg} / \mathrm{kg}$ live weight respectively (Figure 3 ) shows that the parasitic load of lot 2 is significantly higher 


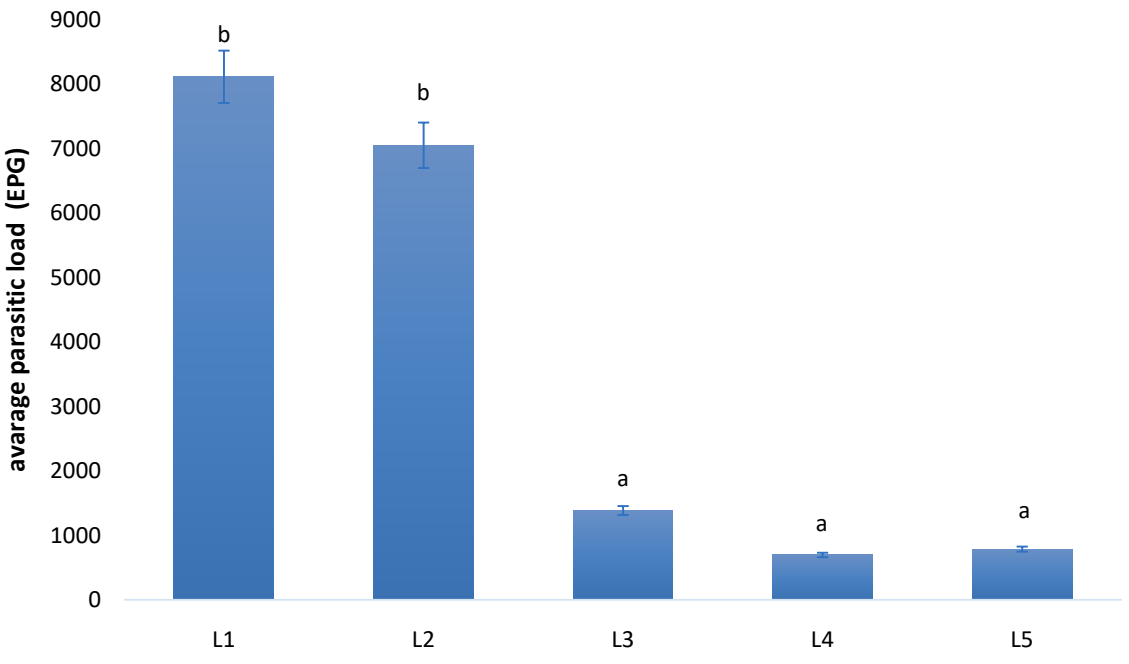

Figure 2. Average parasitic load per lot. $(a, b)$ Average EPGs with the same letters are statistically comparable $(\mathrm{P}>0.05)$.

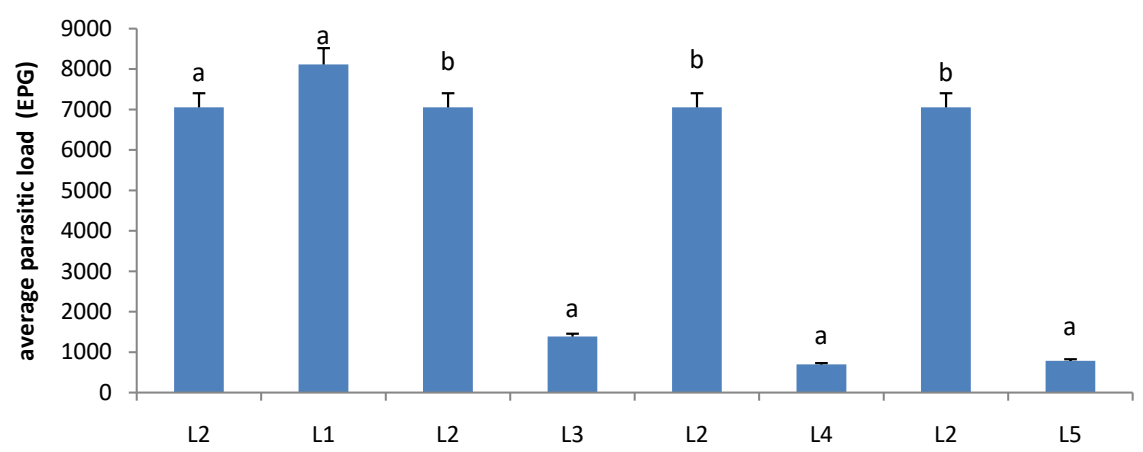

Figure 3. Average parasitic load of animals treated with sulfonamide and plant extract. (a, b) Average EPGs with the same letters are statically comparable $(\mathrm{P}>0.05)$.

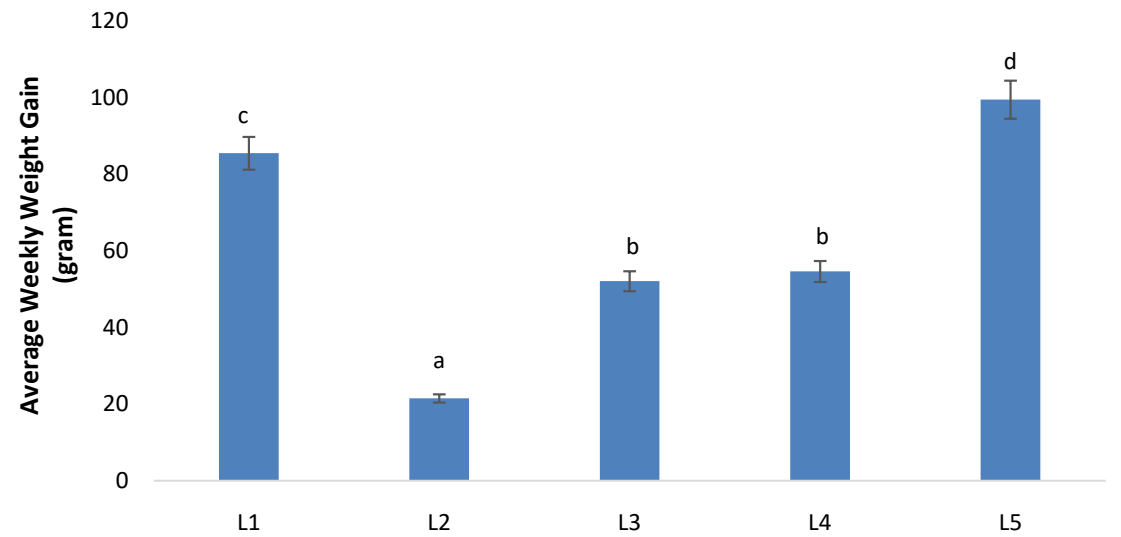

Figure 4. Average weekly weight gain of each lot (a, b, c, d) AWWGs with the same letters are statistically comparable $(\mathrm{P}>0.05)$.

$(\mathrm{P}<0.05)$ than those of lots 3 (with $\mathrm{F}=6.149$ and $\mathrm{N}=3$ ) and 4 (with $\mathrm{F}=6.459$ and $\mathrm{N}=3$ ). The same observation was made between lots 2 and 5 (with $\mathrm{F}=$ 6.335 and $\mathrm{N}=3$ ). However, the parasitic loads of lots 1 and 2 are comparable and not significant $(\mathrm{P}>0.05$ with $\mathrm{F}=2.528$ and $\mathrm{N}=3)$. 


\subsection{Weekly Weight Gain of Young Rabbits}

Growth expressed as weight gain (Figure 4) shows that the average weekly weight gain $(A W W G)$ of each batch after treatment increased significantly $(\mathrm{P}<0.05)$ with the increasing doses of hydro-ethanolic extract of leaves of $A$. annua L. Although, lots 3 and 4 remained comparable ( $P>0.05$ ), the highest AWWG was recorded with in lot 5 that received $1200 \mathrm{mg}$ of hydro-ethanolic extract of mugwort leaves per kilogram of live weight. However, the lowest was recorded in lot 2 treated with sulfonamide.

\section{Discussion}

Throughout the control phase of oocystal excretions, no subject treated with the extract presented an adverse clinical effect, although no biochemical test was performed to assess the toxicity of the extract. This would explain the widespread use of mugwort. In addition, the absence of mortality in lots treated with Artemisia annua testifies to a protection conferred to the animals. [31] obtained similar results with Artemisia annua L. following the incorporation of the Artemesia into the broiler diet during an experimental infection with Eimeria tenella.

The reduction in oocyst excretion observed in the control group, which received no treatment (lot 1), could be explained by the occurrence of intense destruction of cells in the intestine of these rabbits, which causes the interruption of Eimeria in the in vivo development cycle [32].

The growth of the animals in the different treated lots was significantly higher than that of the lot treated with sodium sulfadimerzine. In addition, the best growth was obtained with lot 5. The use of the hydro-ethanolic extract of Artemisia annua L. at $1200 \mathrm{mg}$ per $\mathrm{kg}$ of live weight therefore significantly improved the growth of the animals during treatment compared to other lots. These results are consistent with those of [33] for whom, the addition of leaf powder and Artemisia extract in poultry feed have the potential to improve daily weight gain and feed conversion rate. These findings are also similar to those of [15], who found that the use of Artemisia annua (5\%) mitigates the negative effect of Eimeria tenella infection on broiler performance. Indeed, the chemical analysis of Artemisia annua showed a good balance of nutrients with high levels of antioxidants that potentiates its successful integration into poultry feed. [34] also showed that Artemisia annua extracts improve weight gain and feed efficiency during an infestation by Eimeria tenella in poultry.

During this study, the toxicological effects of the use of the hydroethanolic extract of Artemisia annua L. have not been established. However, the observation of the animals which received this extract by gavage did not suggest any abnormality in their behavior.

\section{Conclusion}

At the end of this study on the effect of Artemisia annua L. as substitute to sulfonamides (sodium sulfadimerzine) on coccidiosis and growth performance in 
rabbits it appears that the evaluation of the effectiveness of the ethanolic extract of Artemisia annua L. leaves at concentrations of $400 \mathrm{mg} / \mathrm{kg}, 800 \mathrm{mg} / \mathrm{kg}$ and $1200 \mathrm{mg} / \mathrm{kg}$ in the treatment of rabbit coccidiosis caused by Eimeria sp. naturally infested rabbits, have shown that this plant has significantly superior anticoccidial properties to that of sodium sulfadimerzine at a dose of $400 \mathrm{mg} / \mathrm{kg}$. Also, the result at the zootechnical level showed an improvement in the growth performance of the rabbits and the best improvement was at the dose of $1200 \mathrm{mg} / \mathrm{kg}$ live weight. Although the results of this study are satisfactory with $400 \mathrm{mg}$ of $A$. annua L. extract, we suggest emphasizing this work by isolating the active ingredient from the extract to allow easier use.

\section{Conflicts of Interest}

The authors declare no conflicts of interest regarding the publication of this paper.

\section{References}

[1] Ngoula, F., Padjinou, D., Yves, K.A., Tadondjou, C.D., Zambou, H.R., Kagou, N.G., Kana, J.R., Defang H.F., Nouboudem, S., Fonteh, A.F., Tegui, A., Pamo, T.E., Kamtchouing, P., Manjeli, Y. and Tchomboue, J. (2014) Effects of the Amprolin300 Ws on Some Parameters of Growth and Reproduction in Male Rabbit (Oryctolagus cuniculus). Journal of Applied Biosciences, 79, 6788-6798. https://doi.org/10.4314/jab.v79i1.4

[2] Boka, O.M. (2006) Evaluation of the Effect of the Anticoccidials Ionophores on the Zootechnical Performances of Broiler Chickens in Semi-Industrial Breeding. Thesis of Veterinary Medicine, University Cheick Anta Diop of Dakar, Dakar, 100 p.

[3] Tchoumboué, J. and Teguia, A. (2004) Bases of the Rabbit Breeding. Department of Animal Production, University of Dschang, Dschang, 36 p.

[4] Othmani-Mecif, K. and Benazzoug, Y. (2005) Characterization of Certain Biochemical, Plasmatic and Histological Parameters (Genital Tract Female) at the Local Population of Rabbit (O. cuniculus) Not Pregnant and during Gestation. Sciences and Technology, 23, 91-96.

[5] Lebas, F. and Colin, M. (2000) Rabbit Meat Production and Consumption in the World. International Journal of Rabbit Breeding. International Days of Rabbit Breeding. UTAD Vila Real, Portugal, 9 p.

[6] Tchoumboué, J. (2010) Animal Production and Veterinary Medicine. 3rd Edition, University of Dschang, Dschang, 154 p.

[7] Grès, V., Marchandeau, S. and Landau, I. (2002) Description of a New Species of Eimeria (Coccidia, Eimeridea) in Wild Rabbit (Oryctolagus cuniculus) in France. Zoosystema, 24, 203-207.

[8] Thoto, M.C.J. (2006) Use of Robenidine (CycostatND 66G) as Anticoccidial Additive in Food: Effect on the Growth and the Degree of Infestation of Rabbits to the Fattening. Thesis of Veterinary Medicine, University Cheick Anta Diop of Dakar, Dakar, 65 p.

[9] Maziz-Bettahar, S., Aissi, M., Ainbaziz, H., Bachene, M.S., Zenia, S. and Ghisani, F. (2018) Prevalence of Coccidian Infection in Rabbit Farms in North Algeria. Veterinary World, 11, 1569-1573. https://doi.org/10.14202/vetworld.2018.1569-1573

[10] Duszynski, D.W. and Couch, L. (2013) The Biology and Identification of the Cocci- 
dia (Apicomplexa) of Rabbits of the World. Elsevier, Amsterdam.

[11] Szkucik, K., Pyz-Lukasik, R., Szczepaniak, K.O. and Paszkiewicz, W. (2014) Occurrence of Gastrointestinal Parasites in Slaughter Rabbits. Parasitology Research, 113, 59-64. https://doi.org/10.1007/s00436-013-3625-7

[12] Pakandl, M. (2009) Coccidia of Rabbit: A Review. Folia Parasitologica, 56, 153-166. https://doi.org/10.14411/fp.2009.019

[13] Yin, G., Goraya, M.U., Huang, J., Suo, X., Huang, Z. and Liu, X. (2016) Survey of Coccidial Infection of Rabbits in Sichuan Province, Southwest China. SpringerPlus, 5, Article No. 870. https://doi.org/10.1186/s40064-016-2586-6

[14] Williams, R.B. (2006) Relative Virulence of a Drug-Resistant and a Drug Sensitive Strain of Eimeria acervulina, a Coccidium of Chickens. Veterinary Parasitology, 135, 15-23. https://doi.org/10.1016/j.vetpar.2005.11.004

[15] Hady, M.M. and Zaki, M.M. (2012) Efficacy of Some Herbal Feed Additives on Performance and Control of Cecal Coccidiosis in Broilers. APCBEE Procedia, 4, 163-168. https://doi.org/10.1016/j.apcbee.2012.11.028

[16] Efferth, T., Romero, M.R., Wolf, D.G., Thomas, S., Marin, J.J.G. and Manfred, M. (2008) The Antiviral Activities of Artemisinin and Artesunate. Clinical Infectious Disease, 47, 804-811. https://doi.org/10.1086/591195

[17] Allen, P.C., Lydon, J. and Danforth, H.D. (1997) Effect of Components of Artemisia annua on Coccidia Infection in Chickens. Poultry Science, 76, 56-63.

https://doi.org/10.1093/ps/76.8.1156

[18] Youn, H.J. and Noh, J.W. (2001) Screening of the Anticoccidial Effect of Herb Extracts against Eimeria tenella. Veterinary Parasitology, 96, 257-263. https://doi.org/10.1016/S0304-4017(01)00385-5

[19] Naidoo, V., McGaw, L.J., Bisschop, S.P.R., Duncan, N. and Eloff, J.N. (2008) The Value of Plant Extracts with Antioxidant Activity in Attenuating Coccidiosis in Broiler Chickens. Veterinary Parasitology, 153, 214-219. https://doi.org/10.1016/j.vetpar.2008.02.013

[20] Service Chrétien d'Appui à l'Animation Rurale (1995) Artemisia annua: Fiche technique de culture (Madagascar-Cameroun).

http://www.secaar.org/documents/documentation/SA6 ARTE.pdf

[21] Njomnang, S.P. (2008) Search of New Compounds with Antipaludic Activity Starting from Various Traditional Pharmacopeias. Thesis of Doctorate, University of Toulouse, Toulouse, $73 \mathrm{p}$.

[22] Benayache, F. (2009) Searching and Structural Determination of the Secondary Metabolites of Centaurea nicaeensis All. Walliana M. (Asteraceae): Study of the Phase Acetate of Ethyl of the Alcoholic Hydro Extract. Memory of Magister in Organic Chemistry. University Mentouri, Constantine, $46 \mathrm{p}$.

[23] Muthamilselvan, T., Kuo, T.F., Wu, Y.C. and Yang, W.C. (2016) Herbal Remedies for Coccidiosis Control: A Review of Plants, Compounds, and Anticoccidial Actions. Evidence-Based Complementary and Alternative Medicine, 2016, Article ID: 2657981. https://doi.org/10.1155/2016/2657981

[24] Hong, S., Mi-Na, M., Eun-Kyung, I., Jum-Soon, W., Ji-Hyun, Y. and Okjin, K. (2018) Anti-Coccidial Activity of the Ethanol Extract of Tribulus terrestris Fruits on Eimeria tenella. Laboratory Animal Research, 34, 44-47. https://doi.org/10.5625/lar.2018.34.1.44

[25] Prashant, T., Bimlesh, K., Mandeep, K., Gurpreet, K. and Harleen, K. (2011) Phytochemical Screening and Extraction: A Review. International Pharmaceutica Sciencia, 
1, 98-106.

[26] Legendre, H., Saratsi, K., Voutzourakis, N., Saratsis, A., Stefanakis, A., Gombault, P., Hoste, H., Gidenne, T. and Sotiraki, S. (2018) Coccidiostatic Effects of TanninRich Diets in Rabbit Production. Parasitology Research, 117, 3705-3713. https://doi.org/10.1007/s00436-018-6069-2

[27] Kaplan, R.M. (2004) Drug Resistance in Nematodes of Veterinary Importance: A Status Report. Trends in Parasitology, 20, 477-481. https://doi.org/10.1016/j.pt.2004.08.001

[28] Euzeby, J. (1981) Experimental Diagnosis of Helminthoses Animal (Domestic Animals, Animal of Laboratory, Primates). Work Practise Helminthology, Paris, 112-203.

[29] Chollet, J.Y., Martrenchar, A., Bouchel, D. and Njoya, A. (1994) Epidemiology of the Digestive Parasitoses of the Young Bovines in North-Cameroun. Review of Breeding and Veterinary medicine of the Tropical Countries, 47, 365-374. https://doi.org/10.19182/remvt.9073

[30] Kochapakdee, S., Pandey, V.S., Pralomkarm, W., Choldumrongkul, S., Ngampongsai, W. and Lawpetchara, A. (1995) Anthelmintic Resistance in Goat in Southern Thailand. Veterinary Record, 137, 124-125. https://doi.org/10.1136/vr.137.5.124

[31] Drăgan, L., Titilincu, A., Dan, I., Dunca, I., Drăgan, M. and Mircean, V. (2010) Effects of Artemisia annua and Pimpinella anisum on Eimeria tenella (Phylum Apicomplexa) Low Infection in Chickens. Science Parasitology, 11, 77-82.

[32] Michels, M.G., Bertolini, L.C.T., Esteves, A.F., Moreira, P. and Franca, S.C. (2011) Anticoccidial Effects of Coumestans from Eclipta alba for Sustainable Control of Eimeria tenella Parasitosis in Poultry Production. Veterinary Parasitology, 177, 55-60. https://doi.org/10.1016/j.vetpar.2010.11.022

[33] Gholamrezaie, S.L., Mohammadi, M., Jalali, S.J., Abolghasemi, S.A. and Roostaie, A.M.M. (2013) Extract and Leaf Powder Effect of Artemisia annua on Performance, Cellular and Humoral Immunity in Broilers. Iranian Journal of Veterinary Research, 14, 15-20.

[34] Oh, H.C., Uysal, M. and Weaver, P. (1995) Product Bundles and Market Segments Based on Travel Motivations: A Canonical Correlation Approach. International Journal of Hospitality and Management, 14, 123-137. https://doi.org/10.1016/0278-4319(95)00010-A 